\title{
Ponkesdes Development into Community Nursing Center Based Health Promotion Model, Nursing Center and Behavioral Performance
}

\author{
Miftahul Munir (Corresponding author) \\ Doctoral degree from School of Public Health, Airlangga University, Indonesia \\ Email: hmiftachulmunir@gmail.com
}

Nursalam

School of Nursing, Airlangga University, Indonesia

\section{R.S. Triyoga}

School of Public Health, Airlangga University, Indonesia

Doi:10.5296/ijhrs.v5i4.8313 URL: http://dx.doi.org/10.5296/ijhrs.v5i4.8313

\begin{abstract}
Introduction: The vision of development in East Java is to realize a prosperous society and morals. In order to improve public health, as one of the measures to achieve this vision will require proximity access and improving the quality of health services in the community. Health cottage village (Ponkesdes) is a basic health services located in the village or villages that are part of the development of village midwife (Polindes). The aim of this study was to develop into a Community Nursing Center Ponkesdes based Health Promotion Model Theory, Nursing Center, and Performance Behavior nurse.

Methods: The study design was an observational analytic consisting of two phases, namely the implementation of the exploratory and descriptive exploration causa effect. The population used in this study were nurses ponkesdes Tuban district that fit inclusion criteria as much as 20 , with a sample of 20 respondents were determined using simple techniques saturated. The independent variable in this study is Nursing Center, Health Promotion and Behavior Model Performance dependent variable is the commitment and the action plan ponkesdes duty nurse. Instruments used in the collection of data in the form of questionnaires and data results focused discussion. Analysis of studies using the Partial Least Square.
\end{abstract}

Results: This study showed a significant effect on Nursing Center nurse commitment Ponkesdes $(t=3.197)$. Health Promotion Model a significant effect on the commitment of 
nurses Ponkesdes $(\mathrm{t}=2.185)$. Commitment nurses significantly influence nurses task Ponkesdes $(\mathrm{t}=29.546)$.

Discussion and Conclusions: Model development of community nursing center Ponkesdes be very relevant to be applied to programs that can improve the health and can be a solution for institutions of public health services.

Keywords: Ponkesdes, Nursing Center, Health Promotion Model, Performance, Community Nursing Center

\section{Introduction}

Vision of development in East Java is to realize a prosperous society and morals. In order to improve public health, as one of the measures to achieve this vision will require proximity access and improving the quality of health services in the community. East Java Provincial Government has run Ponkesdes since 2010 aiming to bring health services to the community. The hope the public will more easily gain access to health care, one of the main elements in the welfare of society is a healthy society. However, in its application, there are still many problems.

Results of the evaluation of the Health Office Distrik Tuban in 2013, the program Ponkesdes experience bebarapa first constraint technical constraints, coverage 20 families assisted per year is only $10 \%$ fulfilled, the inability of officers ponkesdes in charging instrument cohort, unavailability format care to patients, the public has not understood Ponkesdes function. Non-technical constraints of inadequate infrastructure, the operational budget Ponkesdes not yet available, the standard salary Ponkesdes officer still under the Minimum Wages District (UMK) in 2013.

Efforts need to be done in order to improve health services in Ponkesdes is to improve the quality of nurses in Ponkesdes. In a scientific study would require a concept or a model that can be applied to solve the existing problems. In this case the author tries to apply the concept of Community Nursing Center-based nursing centers, Health Promotion Model, and behavioral performance. The concept of nursing centers include community involvement, involvement of educational institutions, caring nurses themselves, and the involvement of professional organizations. The concept of Health Promotion Model (HPM) is how an individual is able to make health care decisions for themselves in the context of nursing. Especially in decision-making and action needed individuals in disease prevention. Health Promotion Model has components (interpersonal influences, situational influences, self efficavy, related activities, the perceived benefits of action, and the obstacles in the act).

While the concept of Performance Behaviors, where the performance contains two major components, the first is the organization, individuals have the ability to identify levels of performance, both productivity that competence must be interpreted as an act or activity which is appropriate to achieve the work. Determination of performance is necessary for an institution or individual can determine whether they have been successful in achieving its 
objectives. In theory the behavior and performance organization focused on factors that include ponkesdes organizational structure, financing ponkesdes, and details of the task.

\section{Research Method}

The study design was an observational analytic consisting of two phase, namely the implementation of the exploratory and descriptive exploration causa effect. The population used in this study were nurses ponkesdes Tuban district that fit inclusion criteria as much as 20 , with a sample of 20 respondents were determined using simple techniques saturated . The independent variable in this study is Nursing Center, Health Promotion and Behavior Model Performance dependent variable is the commitment and the action plan ponkesdes duty nurse. Instruments used in the collection of data in the form of questionnaires and data results focused discussion. Analysis of studies using the Partial Least Square. The research procedure was used in that study would be Described:

Procedure ponkesdes into nursing research development center, the first step begins with identifying factors that include factors terkai nursing center with indicators (community involvement, the involvement of educational institutions, caring nurses, health care involvement, the involvement of professional organizations ), health promotion model ( interpersonal influences, situational influences, self efficacy, related activities, the benefits of the actions perceived obstacles in acting ), commitment and duty nurse . Hhasil identification analyzed to create the instrument, the instrument was applied to the nurse to analyze the influence of each other . Results of the analysis instrument is used to create a "model community nursing center Indonesia ".

\section{Result and Analysis}

Table 5.1 Coefficient Parameter Path to Construct Latent Effects of Direct and Indirect Between Variables

\begin{tabular}{|c|c|c|c|c|c|}
\hline No & $\begin{array}{l}\text { Direct and indirect } \\
\text { influence between } \\
\text { endogenous and } \\
\text { exogenous variable }\end{array}$ & $\begin{array}{c}\text { Path } \\
\text { Coefficient } \\
\text { parameter }\end{array}$ & $\begin{array}{c}\text { Sample } \\
\text { Mean (M) }\end{array}$ & $\begin{array}{l}\text { Standa } \\
r \\
\text { Error }\end{array}$ & $\begin{array}{l}\text { T-Stat } \\
\text { Value }\end{array}$ \\
\hline 1 & $\begin{array}{l}\text { Effect of Nursing } \\
\text { Center for commitment }\end{array}$ & 0,801 & 0,876 & 0,250 & 3,197 \\
\hline 2 & $\begin{array}{l}\text { Effect of Health } \\
\text { Promotion Model } \\
\text { (HPM) on commitment }\end{array}$ & $-0,147$ & $-0,150$ & 0,067 & 2,185 \\
\hline 3 & $\begin{array}{l}\text { Influence commitment } \\
\text { to duty nurse } \\
\text { ponkesdes }\end{array}$ & 0,877 & 0,904 & 0,030 & 29,546 \\
\hline
\end{tabular}

Nursing Center analysis showed a significant effect on the commitment of nurses Ponkesdes $(t=3.197)$. Health Promotion Model a significant effect on the commitment of nurses Ponkesdes $(\mathrm{t}=2.185)$. Commitment nurses significantly influence nurses task Ponkesdes $(\mathrm{t}$ $=29.546)$. 


\section{Macrothink}

International Journal of Human Resource Studies

ISSN 2162-3058 2015, Vol. 5, No. 4

Ponkesdes development model into community nursing center based nursing centers, health promotion and behavioral models of performance according to the results of modeling are described below:

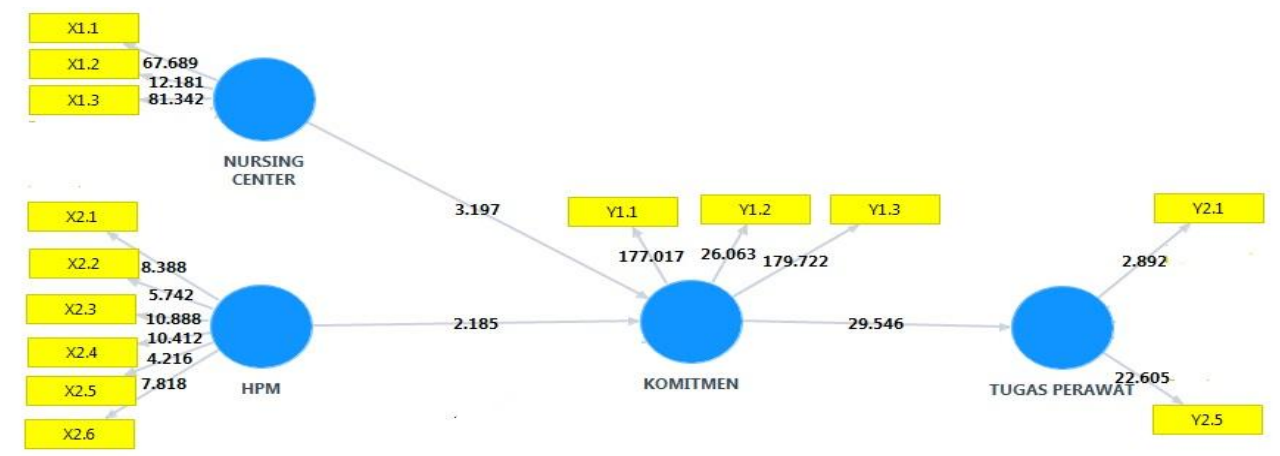

Figure 2. Model development ponkesdes be a community nursing center based on pathway analysis.

\subsection{Effect of nursing center for nurses Ponkesdes commitment.}

The influence of nursing centers (community involvement, educational institutions, caring nurses, health care involvement, and the involvement of professional organizations) to the nurse's commitment to the value ponkesdes T-statistic of 3.197 ( $\mathrm{T}$ count>1.96).

The results showed that the majority of respondents factors nursing center is still lacking, it is proved that each sub-variables nursing centers are in the position of the category of less, but for the involvement of most of the health services in both categories. While the results of the factor analysis nursing center (community involvement, educational institutions, caring nurses, health care involvement, and the involvement of professional organizations) affect the commitment of nurses ponkesdes.

Results were in accordance with the explanation Suharyati, that the nursing center is integrated in the service management, education and nursing research through the empowerment of all the existing potential optimally. In the nursing center has always strived to regard nursing as a unified whole, so that the nursing center has certain characteristics ${ }^{(16)}$. Community Nursing Center (CNC) serves as a liaison on the first level among members of vulnerable populations and also provide the health care system as close as possible to the public ${ }^{(9)}$. CNC sets guidelines for providing care by organizations that provide services to improve the health status of individuals, families and communities through direct access to nursing ${ }^{(9)}$.

Coherence in the planning and implementation and evaluation of educational programs, services, and research or development keparawatan. The integration of management in education, care, and nursing research is needed to achieve synergy in each step of management. With the management integration will occur empowerment of all the existing potential optimally. It required an awareness, openness and togetherness in the face of task 
implementation services, education and research are seen as a shared responsibility. To be able to optimize all the potential, it needs personal perception of the entire nursing community involved against both external and internal nursing community. Internally nursing, perception can be obtained via the scientific community to build community nursing, where all members of the profession united in developing the community nursing both in theory and practice. Externally, the common perception is also absolutely necessary from all stakeholders associated with all public health efforts through collaboration with various sectors ${ }^{(16)}$.

Community empowerment in the health sector is the main target of health promotion. According to WHO, there are three main strategies to achieve the vision and mission of effective health promotion, through advocacy, social support and community empowerment. Community empowerment in the health sector can not be separated from the actual empowerment of society in general, where empowerment is generally an attempt or process to raise awareness, willingness, overcome, nurture, protect and improve the welfare of their own.

\subsection{Effect of Health Promotion Model for the commitment of nurses Ponkesdes}

Shows the influence of Health Promotion Model (interpersonal influences, situational influences, self-efficacy, related activities, the perceived benefits of action and to act perceived inhibitors) against nurses ponkesdes commitment to the value of the T-statistic of 2.185 ( $\mathrm{T}$ count $>1.96$ ).

The results showed that the majority of the Health Promotion Model (HPM) of respondents in the medium category, it is proved that each sub-variables Health Promotion Model (HPM) in the sub variables related activities, the perceived benefits and barriers in the act low category. As for the influence of interpersonal and situational influences are positioned higher category. Results of factor analysis explains Health Promotion Model (perceived benefits of action, perceived obstacle to action, self efficacy, related activity, interpersonal influence, and the influence of situational) was significantly commitment Ponkesdes nurse. Variables (perceived benefits of action, perceived obstacle to action, self efficacy, related activity, interpersonal influence, and the influence of situational) provide a strong influence on commitment. According to Bandura, a person's ability to organize and carry out major actions concerning not only the skills of a person but the decision taken someone of skill possessed ${ }^{(1)}$.

Health Promotion Model variable factors perceived benefits of action, perceived obstacle to action, self-efficacy and related activities, according to Pender outlines that interest is a source of motivation that drives a person to do what he wants to do when free to choose ${ }^{(12)}$. When someone considers that something would be beneficial, then it would be interested in, then it will bring satisfaction. When satisfaction decreased, the interest will also decrease. So that the interest is not permanent, but temporary interest or can be fickle ${ }^{(12)}$. The same thing was also stated by Prawirosentono that an activity will be performed or not is dependent at all by the interest of someone for the event, here appears that interest is a powerful motivator to perform an activity ${ }^{(13)}$. Samsudin defines the interest is strong concern, commitment and control of in-depth individual to diligently perform an activity. From some of the above theory can be deduced about interest, that interest is an intrinsic motivation as a force 
learning the driving force someone in an activity with great diligence and tend to settle, where such activity is a process of learning experiences made with full awareness and bring a sense of excitement, love and joy ${ }^{(15)}$.

Knowledge of perkesmas adequate, their interests and desires, but support budget for operational costs, infrastructure and less wages not even exist, would be a major barrier to the stalled perkesmas. Troubleshooting is also appropriate recommendations of the FGD at the fourth point is the commitment to the plan of action is still low in the discharge perkesmas with the recommendation: Increase the facilities and infrastructure that support the obligations and activities Ponkesdes, make suggestions salary increase nurses ponkesdes of professional organizations PPNI, because of the gap salaries among nurses and midwives polindes, hoping if salary meet the standard could still be set aside for the activities of the home or home care visits, and scheduling of activities that balance between promotive, preventive and curative.

Interpersonal influences affecting the nurse's commitment can be seen from the factors that influence the success of the performance of nurses is communication. Pender also states that the working partner community nurse is the patient himself, colleagues and the environment in which nurses do home care. All patients are basically always expect a corresponding optimal service they expect even more than what they expect ${ }^{(12)}$. This interpersonal communication process if the implementation does not conform to the ways of doing that then the resulting communication is a response to rejection or dissatisfaction of the patient of what they feel when getting services. Results of this study can be concluded that the nurse Ponkesdes still require additional provisioning, especially in terms of communication, whether in the form of seminars, training and workshops. Deepening the science of this communication should be directed to social communication as approach with religious leaders, community leaders and other health team.

\subsection{The influence of nurses on duty nurse commitment Ponkesdes}

Shows the influence of nurses on duty nurse commitment Ponkesdes (environmental health, nutritional health, disease prevention, health promotion, and simple treatment) with the value of the T-statistic of 29.546 ( $\mathrm{T}$ count $>1.96$ ).

The results showed that the majority of nurses commitment Ponkesdes in Tuban felt good, it is proved that each sub variable commitment to be positioned either category. Similarly Task Ponkesdes nurse at Tuban majority felt good, it is proved that each sub variable duty nurse Ponkesdes be positioned either category. Results of the analysis explains the influence of the nurse's commitment to the role of nurses Ponkesdes.

Results were in accordance with the opinion of Trisnaningsih outlines that interest is a source of motivation that drives someone to do what he wants to do when free to choose. When someone considers that something would be beneficial, then it would be interested in, then it will bring satisfaction. When satisfaction decreased, the interest will also decrease ${ }^{(17)}$. So that the interest is not permanent, but temporary interest or can be fickle. Interests nurse Ponkesdes since the beginning it was very high for the service in the health sector in East Java, but once again the nurse salary factors that trigger the fall of the interest of nurses to serve in the end the commitment will decline as well. This condition is consistent with the 
theory presented by Trisnaningsih ${ }^{(17)}$.

Intentions, the words of the Prophet Muhammad: "Inasmuch deeds that (subject) with the intention." And everyone will get results according to intention does. Intention is a behavior that emerged in response terhahadap object. Intention is also the interest of behaving that emerged in response to the object. Intention is also an interest in re behave that shows the desire of individuals to perform the behavior. Ponkesdes nurse intention to do perkesmas actually there, because this perkesmas activity is one of the main tasks of nurses in the community. So with more and intend to do perkesmas will mean more commitment to implement.

Prawirosentono explains that an employee's performance will be good, if the employee has a high skill, willingness to work, the reward / decent wages and have hope for the future. Theoretically, there are three groups of variables that influence the work behavior and performance of individuals, namely: individual variables, organizational variables and psychological variables. Group individual variables consist of variable abilities and skills, personal and demographic backgrounds ${ }^{(13)}$.

Gibson also states that the variable abilities and skills are the main factors that influence the behavior and performance of individual work. Demographic variables have an indirect influence ${ }^{(4)}$. Kopelman explains, the variable remuneration will affect the motivation variable, which in turn directly affects the performance of individuals ${ }^{(8)}$. Research Robinson and Larsen to the employees of rural health workers in Colombia showed that the rewards have greater influence on employee performance compared to the group of employees who were not given ${ }^{(6)}$. Mitchell in Timpe stated that the motivation is individual, in the sense that everyone is motivated by a variety of influences to varying levels ${ }^{(18)}$. Improved performance of the individual in the organization nmenuntut managers to take an indirect approach, creating motivation through organizational atmosphere that encourages employees to be more productive. This atmosphere is created through the management of organizational factors in the form of reward system settings, structures, job design and maintenance of communication through leadership practices that encourage mutual trust.

Overall explained that the individual commitments which include high employee involvement makes someone unites himself with the work, investing time and energy to work and critical regard employment as a major part of his life ${ }^{(17)}$. The stronger the commitment, the stronger the tendency sesrang to be directed in accordance with the standard action ${ }^{(17)}$. The results showed that the majority of nurses commitment Ponkesdes in Tuban felt good, it is proved that each sub variable commitment to be positioned either category. Similarly Task Ponkesdes nurse at Tuban majority felt good, it is proved that each sub variable duty nurse Ponkesdes be positioned either category. Results of the analysis explains the influence of the nurse's commitment to the role of nurses Ponkesdes Ponkesdes.

\section{Conclusion}

Ponkesdes as health care facilities still need to be developed . Nursing center has a strong influence on commitment. Factor model of health promotion has an influence on commitment. Commitment has an influence on nursing duties . Ponkesdes development model into nursing center is the development of confirmation of the theory developed models of health promotion and nursing center models by substituting reinforcing factors. Ponkesdes be a 
community development model is very relevant nursing center applied to the public health service facilities.

\section{Acknowledgements}

The authors would like to thank the team of researchers in Tuban, Indonesia. This paper could not have happened without the work and dedication to developing innovative ponkesdes be a community nursing center.

\section{References}

[1] Bandura A. Social foundations of thought and action: A social cognitive theory. Englewood Cliffs, NJ: Prentice Hall; 1986.

[2] Bandura A. Self-efficacy mechanism in physiological activation and health-promoting behavior. In J. Madden. IV (ed), Neurobiology of learning, emotion and affect New York; Raven; 1991. p. 229-270.

[3] Gibson dan Ivancevich. Organisasi, Perilaku, Struktur, Alih Bahasa: Zuhad Ichyaudin, Jakarta: Erlangga; 1996.

[4] Gibson, James L, John M, Ivancevich, James H, Donnelly, Jr, and Robert Konopaske. Organizations: Behavior, Structure, Process (Eleventh Edition), Boston: McGraw-Hill Irwin; 2003.

[5] Gomes dan Faustino C. Manajemen Sumber Daya Manusia, Yogyakarta: Andi Offset; 2003.

[6] Jones Pam. Buku Pintar Manajemen Kinerja, Alih Bahasa: Anthony RI. Jakarta: Metalexia Publishing \& PT Qreator Tata Qarakter; 2002.

[7] Keban YT. Enam dimensi strategis administrasi publik, Konsep, Teori dan Isu, Jakarta: Gava Media; 2004.

[8] Kopelman RE. Managing Productivity in Organizations: A Practical, People-Oriented Perspective, New York : McGraw-Hill Book Co; 1986.

[9] Newman DM. A Community Nursing Center for the Health Promotion of Senior Citizens Based on the Neuman System Model. Journal of Community Nursing Center. 2005. Vol. 26, No. 4.

[10] Notoadmojo S. Metodologi Penelitian Kesehatan, Jakarta: EGC; 2005.

[11] Nursalam. Konsep Dan Penerapan Metodologi Penelitian Ilmu Keperawatan, Jakarta: Salemba Medika; 2003.

[12] Pender N., Murdaugh C. \& Parsons M. Health Promotion In Nursing Practice. 6th ed. Michigan USA: Upper Sadle River, NJ Pearson/Prentice-Hall; 2010.

[13] Prawirosentono S. Kebijakan Kinerja Karyawan, Yogyakarta: BPFE; 1999.

[14] Robbins SP. Perilaku Organisasi: Konsep, Kontroversi, Aplikasi, Alih Bahasa: Hadyana Pujaatmaka, Jakarta: PT. Prenhalindo; 1996.

[15] Samsudin. Manajemen Sumber Daya Manusia, Bandung: Pustaka Setia; 2005.

[16] Suhariyati S. Konsep Nursing Center, Yogyakarta: UGM; 2007.

[17] Trisnaningsih S. Pengaruh Komitmen terhadap Kepuasan Kerja Auditor: Motivasi 


\section{Macrothink}

International Journal of Human Resource Studies

ISSN 2162-3058 2015, Vol. 5, No. 4

sebagai Variabel Intervening (Studi Empiris pada Kantor Akuntan Publik di Jawa Timur), Jurnal Riset Akuntansi Indonesia. 2004. Vol 6, No.2, Mei, 199-216

[18] Wibowo. Manajemen Kinerja, Edisi Ketiga, Jakarta: PT. Raja Grafindo Persada; 2010.

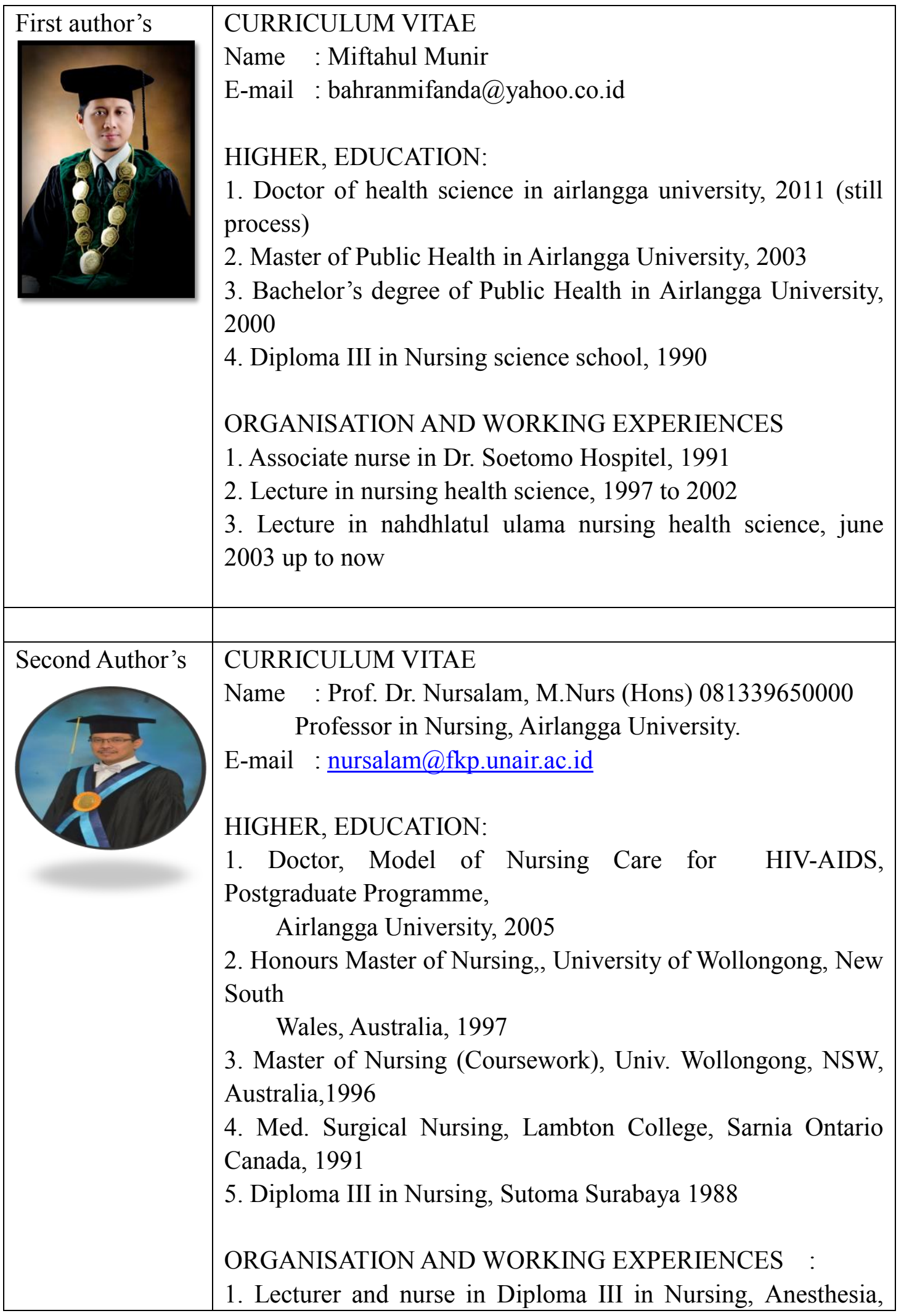




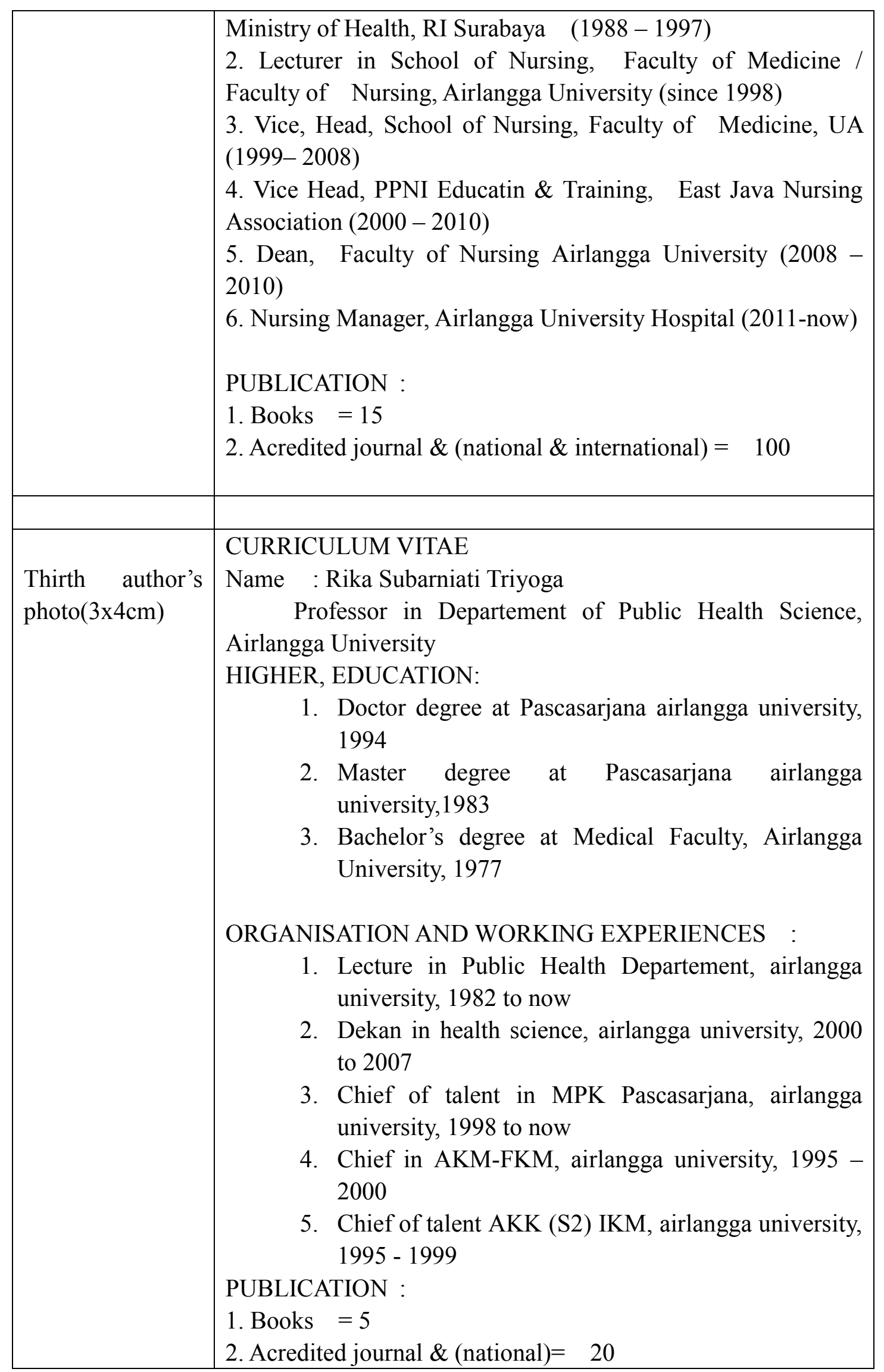

